\title{
Effect of land use on the seasonal variation of streamwater quality in the Wei River basin, China
}

\author{
SONGYAN YU ${ }^{1,2}$, ZONGXUE XU ${ }^{1,2}$, WEI WU ${ }^{3}$ \& DEPENG ZUO ${ }^{1,2}$ \\ 1 College of Water Sciences, Beijing Normal University, Beijing 100875, China \\ 2 Joint Center for Global Changes Studies, Beijing 100875, China \\ zongxuexu@vip.sina.com \\ 3 School of Resources and Environment, University of Jinan, Jinan 250022, China
}

\begin{abstract}
The temporal effect of land use on streamwater quality needs to be addressed for a better understanding of the complex relationship between land use and streamwater quality. In this study, GIS and Pearson correlation analysis were used to determine whether there were correlations of land-use types with streamwater quality at the sub-basin scale in the Wei River basin, China, during dry and rainy seasons in 2012. Temporal variation of these relations was observed, indicating that relationships between water quality variables and proportions of different land uses were weaker in the rainy season than that in the dry season. Comparing with other land uses, agriculture and urban lands had a stronger relationship with water quality variables in both the rainy and dry seasons. These results suggest that the aspect of temporal effects should be taken into account for better land-use management.

Key words water quality; land use; temporal effect; Wei River
\end{abstract}

\section{INTRODUCTION}

Water quality deterioration has been one of the key environmental issues in the world (Palmer et al. 2004). Therefore, numerous studies have attempted to identify the linkage between land use surrounding rivers and streamwater quality. Most of related studies focus on three scales, i.e. basin, sub-basin and riparian scales. The linkage between land use and water quality in different scales were inconsistent (Johnson and Gage, 1997; Allen, 2004; Hurley, 2013; Bu et al., 2014; Ye et al., 2014). The importance of temporal scale for the corresponding relationship should also be noted. Dominant factors on the temporal scale, such as precipitation, temperature and agricultural activities, vary among seasons, and given their role on water chemistry, when non-point source pollution is predominant in the rainy season, agriculture and forest land show stronger association with water chemistry (Ye et al. 2014). Therefore, researchers have suggested that it is necessary to take seasonal variation into consideration when studying the impact of land use on river water quality (Johnson, 1997). Bu (2014) employed statistical and spatial analysis to research the relationship between land-use patterns and river water quality in the Taizi River basin, China, during both dry and rainy seasons, indicating that during the dry season point source pollution was predominant, but in the rainy season water quality showed mixed pollution from both point and non-point sources.

Therefore, more and more attention has been paid to this watershed because of water quality problems. Highly developed agriculture lands have contributed to a high rate of erosion of $30 \%$ with the constant tendency of further increase (Sang et al. 2003). In addition, there are many cement plants, fertilizer factories and mines distributing along the Wei River bank, thus resulting in direct discharge of wastewater into surrounding watercourses due to commercial pursuit and lack of common sense. At the same time, to get higher grain yields, many previously uncultivated areas have also been exploited for agriculture land use and a large number of pesticides and chemical fertilizers applied in the process. What is worse, some forest lands were designed for tourism, causing deforestation activities. Thus the degree of water degradation has accelerated.

The main objectives of this study are to: (1) investigate the relationship between river water quality and land-use types; and (2) detect the relationship between land-use types and river water quality temporal variation of water quality in the Wei River basin, China. 


\section{MATERIALS AND METHODS}

\subsection{Study area description}

The Wei River, the largest tributary of the Yellow River, originates from the north of Niaoshu Mountain at $3485 \mathrm{~m}$ in Gansu province, China, and flows $818 \mathrm{~km}$ with $134.3 \times 10^{4} \mathrm{~km}^{2}$ of drainage areas. The study watershed consists of three catchments, Wei River catchment (W), Jing River catchment (J) and Beiluo River catchment (L), and each one has its special characteristics (Fig. 1). The Wei River catchment is the most developed of the three catchments, which means large amounts of industry and impervious surface; and in the Jing River and the Beiluo River catchments, there were oil extractions which strongly affect surrounding environment (Kang, 2008). In addition, this river, which is a major source of water for drinking, industrial production and irrigation in the Guanzhong plain, plays an important role for the development of economics and society in Western China.

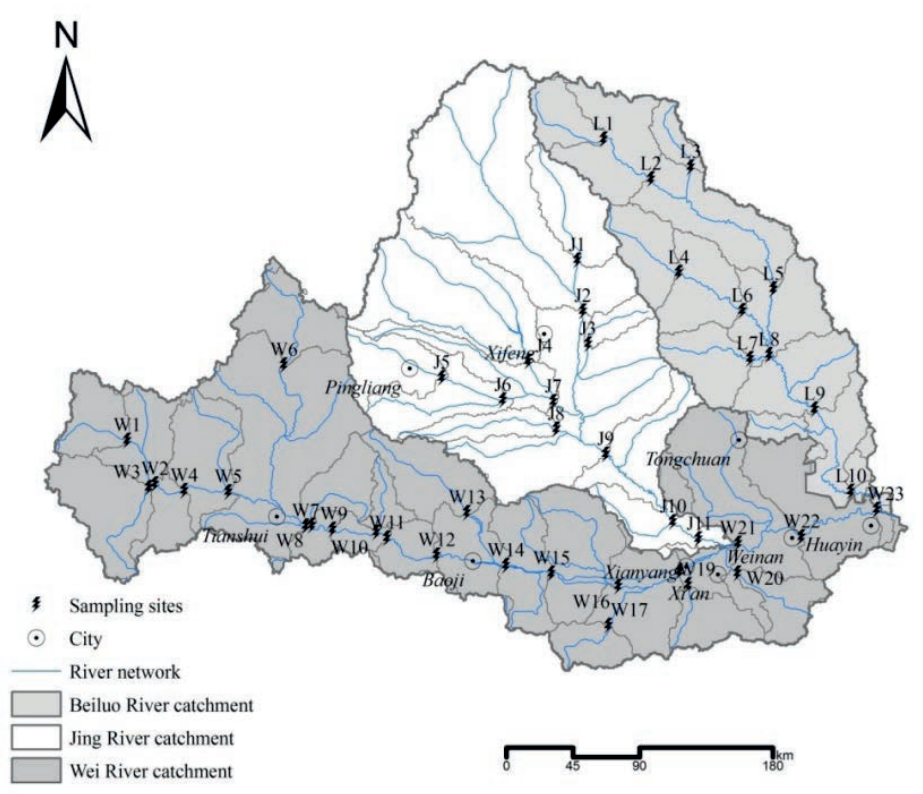

Fig. 1 Study area and location of sampling sites.

\subsection{Water sampling}

Water was sampled in two field surveys along the Wei River during two periods: the dry season (April 2012), and the rainy season (October 2012). In total, 44 sampling sites, comprising 23 sites in the Wei catchment, 11 in the Jing catchment, and 10 in the Beiluo catchment, were sampled in the dry and wet season.

Twelve representative parameters were measured, including $\mathrm{pH}$, dissolved oxygen (DO), electrical conductivity (EC), total dissolved solids (TDS), chloride $\left(\mathrm{Cl}^{-}\right)$, sulfate $\left(\mathrm{SO}_{4}{ }^{2-}\right)$, permanganate index $\left(\mathrm{COD}_{\mathrm{Mn}}\right)$, ammoniacal nitrogen $\left(\mathrm{NH}_{3}-\mathrm{N}\right)$, nitrite nitrogen $\left(\mathrm{NO}_{2}-\mathrm{N}\right)$, nitrate nitrogen $\left(\mathrm{NO}_{3}-\mathrm{N}\right)$, orthophosphate $\left(\mathrm{PO}_{4}{ }^{3-}\right)$, and total phosphorus (TP). The values of $\mathrm{pH}, \mathrm{DO}, \mathrm{EC}$, and TDS were directly measured in situ using a multiparameter water quality monitoring instrument YSI 85. The other parameters were measured in the laboratory according to the national standard criterion (GB 3838-2002).

\subsection{Land-use data}

The land-use map of the Wei River basin was captured in 2007 and divided into six land-use categories: (1) agriculture, including paddy fields and dry land; (2) forest, including shrub land and sparse woodlot; (3) grassland, including different coverage types; (4) water bodies, including rivers, wetlands and sandy beaches; (5) urban, including industrial and residential areas; and 
(6) barren land, including gravels, bare ground and bare rocks. A digital elevation model (DEM) at $30 \mathrm{~m} \times 30 \mathrm{~m}$ resolution was used to delineate the basin area. The Wei River basin was divided into 44 sub-basins based on the locations of the sampling sites. Each sampling site was selected as the outlet point for a discrete sub-basin. Therefore, the effect of land-use composition on water quality was analysed at the sub-basin level.

\subsection{Statistical analysis}

Two statistical features including the mean and standard deviation were calculated for each subbasin. A one-way Analysis of Variance (ANOVA) was performed on the log-transformed water quality values to determine whether the differences between two seasons were significant. Correlations between land use and water quality chemistry were tested by Pearson's correlation with statistical significances at $p<0.05$ level (2-tailed) in both dry and rainy seasons. Before the correlation analysis, the one-sample Kolmogorov-Smirnov test was used to test the normal distribution of all variables.

\section{RESULTS AND DISCUSSION}

\subsection{Land-use distribution}

Figure 2 shows the distribution of land use for each sub-basin in 2007, suggesting that agriculture and grassland were the most common land-use types in the whole basin. Other types, including urban, water bodies and barren land, were a relatively minor component of sub-basins $(<3 \%$ combined for all 44 sub-basins except for W21). It was interesting to find that those sub-basins which have great proportion of urban land use have less grassland and more agriculture land. This observation may be explained by the assumption that the urbanization process used the grass land so as to support more living residents in the city. Because more food was necessary, the agriculture land was retained at a high proportion level (Song et al., 2007).

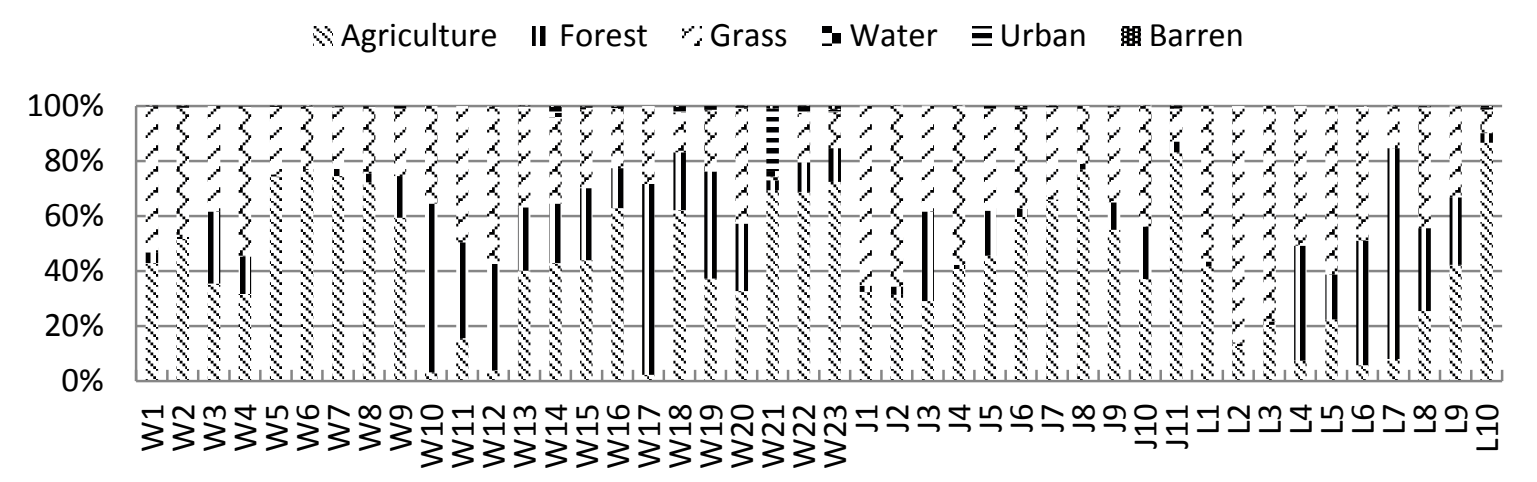

Fig. 2 Land-use distribution at the sub-basin scale.

Agriculture land was the dominant land-use type for all sub-basins with areas ranging from $2.3 \%$ to $86.7 \%$ (mean $43.0 \%$ ). Likewise, significant amounts of grass land were also observed in all sub-basins, ranging from $1.48 \%$ to $86.3 \%$. There was a significant amount of forest land $(>4.0 \%)$ in 26 of the 44 sub-basins, with a maximum of $76.7 \%$ of the total area in one sub-basin (L7). Furthermore, from the catchment perspective, there was least forest land use in the Jing River catchment, and agriculture land use in Beiluo River catchment.

\subsection{Physicochemical water quality properties in the Wei River basin}

No significant temporal change was observed in the ANOVA analysis $(p>0.05)$ for these variables in dry and wet seasons, and these 12 parameters could be used for correlation analysis. 


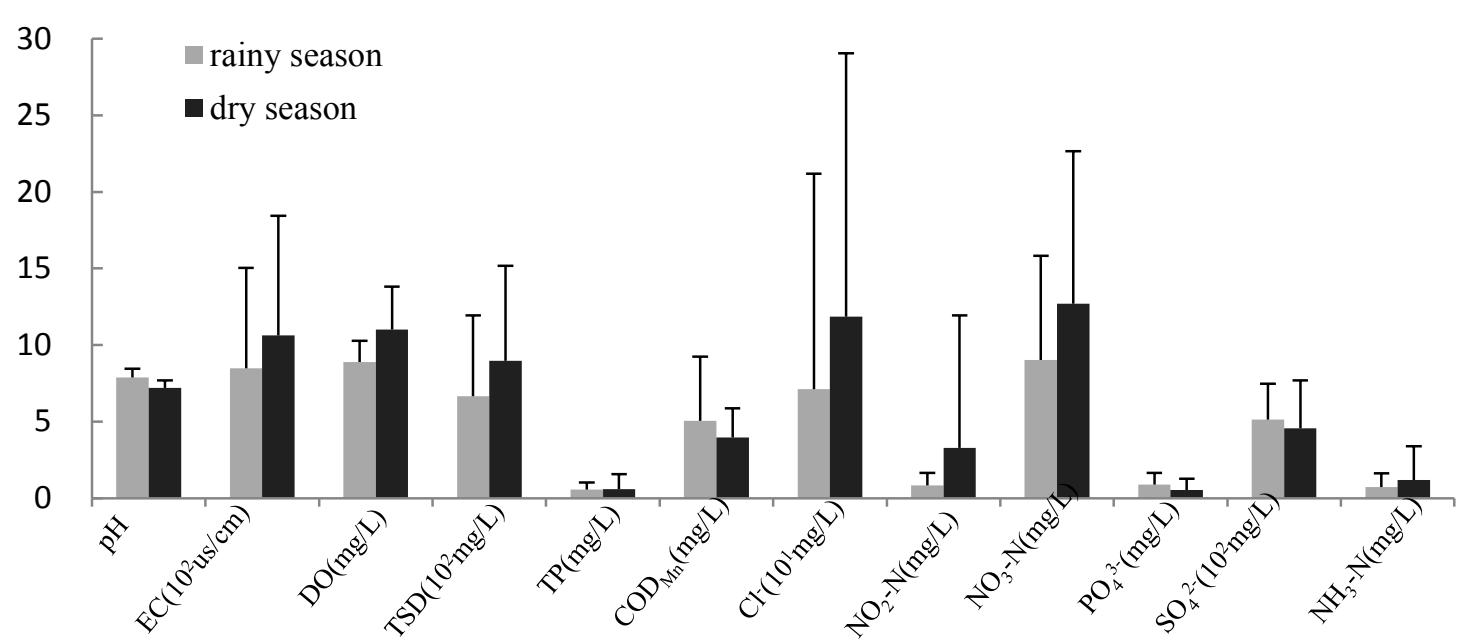

Fig. 3 Physical-chemistry water quality properties in the Wei River basin. Error bars in this figure means standard deviation of each water quality variable.

As shown in Fig. 3, the mean concentrations of EC, DO, TDS TP, $\mathrm{Cl}^{-}, \mathrm{NO}_{2}-\mathrm{N}$ and $\mathrm{NH}_{3}-\mathrm{N}$ were slightly higher in the dry season than in the rainy season. Conversely, the mean concentrations of other parameters were the opposite. This finding was inconsistent with previous studies that suggested a tendency of concentration to increase from dry years to rainy years (Huang, 2013; Bu et al., 2014), partly because of greater inputs of non-point source pollutants to rivers in the rainy season in this study area.

\subsection{Relationship between land use and water quality}

According to the Kolmogorov-Smirnov goodness of fit test, variables (EC, TDS, $\mathrm{COD}_{\mathrm{Mn}}, \mathrm{Cl}^{-}$, $\mathrm{PO}_{4}{ }^{3-}$ and $\mathrm{NH}_{3}-\mathrm{N}$ ) in the dry season and variables (EC, TP, $\mathrm{Cl}^{-}, \mathrm{NO}_{2}-\mathrm{N}, \mathrm{PO}_{4}{ }^{3-}, \mathrm{SO}_{4}{ }^{2-}$, and $\mathrm{NH}_{3}-\mathrm{N}$ ) during the rainy season should be log-transformed for following analysis.

As shown in Table 1, in the rainy season the statistical analysis indicated that several water quality variables were significantly correlated with the proportions of agricultural area, forest area, and grass area, as well as with urban and barren area at a significance level of $>0.95$ (i.e. $p<0.05$ ). However, no water quality variable had a significant correlation with proportion of water bodies but a correlation at a significant of $>0.90$ and $<0.95$. However, from the view of water quality parameters, all parameters except $\mathrm{TP}, \mathrm{COD}_{\mathrm{Mn}}, \mathrm{SO}_{4}{ }^{2-}$ and $\mathrm{NH}_{3}-\mathrm{N}$ were strongly associated with one or more proportions of land-use types. For the dry season, the statistical analysis presented different correlation patterns from those in the rainy season, showing that water quality variables were more influenced by the proportions of all kinds of land uses. All proportions of land-use types had a strong relationship with water quality variables at a significant level $>0.95$ (i.e. $p<$ 0.05 ). However, among the 11 water quality variables considered, most could be explained by land-use variables. $\mathrm{EC}$ and $\mathrm{NO}_{2}-\mathrm{N}$ were strongly associated with as many as three land-use variables. However, no proportion of land use showed significant relationships with $\mathrm{pH}$ value.

\subsection{Temporal differences in relationship between land use and water quality}

In the rainy season, with the exception of $\mathrm{SO}_{4}{ }^{2-}, \mathrm{NH}_{3}-\mathrm{N}, \mathrm{TP}$ and $\mathrm{COD}_{\mathrm{Mn}}$, all water quality variables were correlated with at least one land-use type. The lack of correlation between land use and $\mathrm{NH}_{3}-\mathrm{N}$ suggested that the loading process of $\mathrm{NH}_{3}-\mathrm{N}$ was impacted by many factors that were not confirmed in wastewater discharged by domestic and industrial activities, as concluded by Ahearn (2005). Similar results were obtained by other researchers (Osborne and Wiley, 1988; Sliva and Williams, 2001; Galbraith and Burns, 2007). Agriculture was positively associated with nutrient variables in both rainy and dry seasons, which indicated that the agriculture actually served as a 
Table 1 Pearson's correlation coefficients between land-use types and water quality chemistry during both rainy and dry seasons.

\begin{tabular}{|c|c|c|c|c|c|c|}
\hline & Agriculture land & Forest land & Grass land & Water bodies & Urban land & Barren land \\
\hline \multicolumn{7}{|c|}{ Rainy season } \\
\hline $\mathrm{pH}$ & & & & $-0.461^{*}$ & -0.465 & \\
\hline EC & 0.334 & & 0.396 & & & \\
\hline DO & -0.418 & & & $-0.430 *$ & -0.637 & \\
\hline TDS & $0.300^{*}$ & & 0.418 & & & \\
\hline $\mathrm{Cl}^{-}$ & 0.334 & -0.304 & & & & \\
\hline $\mathrm{NO}_{2}-\mathrm{N}$ & 0.341 & & & & 0.399 & 0.404 \\
\hline $\mathrm{NO}_{3}-\mathrm{N}$ & 0.335 & & & & $0.312 *$ & \\
\hline \multicolumn{7}{|c|}{ Dry season } \\
\hline $\mathrm{EC}$ & 0.525 & -0.344 & 0.436 & & & \\
\hline DO & & & 0.378 & & -0.411 & \\
\hline TDS & 0.429 & & 0.409 & & & \\
\hline TP & & & & $0.404 *$ & & \\
\hline $\mathrm{COD}_{\mathrm{Mn}}$ & & 0.352 & & & 0.425 & 0.471 \\
\hline $\mathrm{Cl}^{-}$ & 0.470 & -0.326 & & & & \\
\hline $\mathrm{NO}_{2}-\mathrm{N}$ & 0.378 & & & 0.544 & 0.454 & \\
\hline $\mathrm{NO}_{3}-\mathrm{N}$ & 0.306 & & & & & \\
\hline $\mathrm{SO}_{4}^{2-}$ & 0.502 & $-0.269^{*}$ & & & & \\
\hline $\mathrm{NH}_{3}-\mathrm{N}$ & 0.342 & & & & 0.406 & \\
\hline
\end{tabular}

Only significant relationships are listed. All $p$-values are less than 0.05 except where indicated. * denotes significant relationship at a level of $p=0.05$ to 1 .

Table 2 Average distance of each land-use type to the corresponding outlet in each sub-basin.

\begin{tabular}{lllllll}
\hline & Agriculture land & Forest land & Grass land & Water bodies & Urban land & Barren land \\
\hline Distance $(\mathrm{m})$ & 41295 & 47441 & 46315 & 44585 & 36088 & 38552 \\
\hline
\end{tabular}

source for pollution in the Wei River basin. The positive relation of urban land with $\mathrm{NO}_{2}-\mathrm{N}, \mathrm{DO}$ and $\mathrm{NO}_{3}-\mathrm{N}$ should also be noted. Urban land was always considered as an important variable that had a negative relationship between the proportion of grass land and water quality variables. However, our results in this study were not in agreement with the anticipation, and only positive correlations between EC, TDS and grassland ( $r=0.396,0.418$, respectively) were identified. The results in this study also suggested that forest land use was closely related to fewer water quality variables than any other land-use type in the rainy season according to the Pearson's correlation analysis, and only a negative correlation between $\mathrm{Cl}^{-}$and forest land was found $(r=-0.304)$. This interesting finding was mainly because the forest land was almost located in the upstream of the watershed, whereas the urban and agriculture areas were chiefly associated with water quality variables (Reimann et al., 2009; Guo et al., 2010). In addition, grass is regarded as a detention vegetation that is helpful to reduce the amount of surface runoff and sediment yield, so that it is reasonable to anticipate situated in the riverine area (Table 2).

In the dry season, agriculture land use were strongly correlated with most physicochemical and nutrient variables, which suggested that agriculture land use had negative effects on river water quality because of intensive fertilization and irrigation during the farming season (Ngoye and Machiwa, 2004). In addition, the relatively small correlation coefficient for urban areas suggested that it was agricultural land, rather than urban land, that was the primary contributor to water quality during the dry season. However, urban land still had a stronger correlation with water quality in the dry season than in the rainy season, such as $\mathrm{NO}_{2}-\mathrm{N}(r=0.399$ and 0.454 in rainy and dry seasons, respectively). Furthermore, this temporal difference for urban land revealed that the degree of river water quality contaminated by possible point sources was relatively high compared to that in the rainy season, because urban land was considered as the proxy of point source by many previous researchers (Karr, 1999). Ahearn et al. (2005) argued that much of the cover in urban areas was impervious and the drainage is frequently routed to wastewater treatment 
plants and then discharged to local rivers as point sources. Compared to the influence of forest land during the rainy season, that in the dry season was much stronger, and more water quality variables were significantly affected, such as $\mathrm{EC}, \mathrm{COD}_{\mathrm{Mn}} \mathrm{Cl}^{-}(r=-0.344,0.352$ and -0.326 , respectively). This result was consistent with other studies (e.g. Bu, 2014).

\section{CONCLUSIONS}

The results of this study demonstrate the relationship between land-use types and streamwater quality during both dry and rainy seasons in 44 sub-basins of the Wei River basin, China. In the rainy season, water quality variables were significantly correlated with the proportions of agriculture, forest, and grass area, as well as with urban and barren area at a significance level of $>0.95$. During the dry season, the statistical analysis presented different correlation patterns from those in the rainy season, showing that water quality variables were more influenced by proportions of all kinds of land uses. In addition, seasonal variation was observed, indicating that the proportion of land-use type had a more significant impact in the dry season than that in the rainy season on the quantity and quality.

Acknowledgements This study is supported by the National Natural Science Foundation of China (51279005). Assistance from editors and reviewers are greatly appreciated.

\section{REFERENCES}

Allan, J.D. (2004). Landscapes and riverscapes: the influence of land use on stream ecosystems. Annual Review of Ecology, Evolution, and Systematics 35, 257-284.

Ahearn, D.S. and Sheibley, R.W. (2005) Land use and land cover influence on water quality in the last free-flowing river draining the western Sierra Nevada, California. Journal of Hydrology 313(3), 234-247

$\mathrm{Bu}, \mathrm{H}$. and Meng, W. (2014) Relationships between land use patterns and water quality in the Taizi River basin, China. Ecological Indicators 41, 187-197

Galbraith, L.M. and Burns, C.W. (2007) Linking land-use, water body type and water quality in southern New Zealand. Landscape Ecology 22, 231-241. doi: 10.1016/j.ecolind.2014.02.003

Guo, Q and Ma, K. (2010) Testing a dynamic complex hypothesis in the analysis of land use impact on lake water quality. Water Resource Management. 24(7), 1313-1332

Herlihy, A.T., Stoddard, J.L. and Johnson, C.B. (1998). The relationship between stream chemistry and watershed land cover data in the mid-Atlantic region, US. In: Biogeochemical Investigations at Watershed, Landscape, and Regional Scales. Springer: Netherlands.

Huang, J. and Pontius, J. (2013) Detecting the dynamic linkage between landscape characteristics and water quality in a subtropical coastal watershed, southeast China. Environmental Management 51(1), 32-44.

Hurley, T and Mazumder, A. (2013) Spatial scale of land-use impacts on riverine drinking source water quality. Water Resource Research. 49(3), 1591-1601.

Johnson, L, and Richards, C. (1997) Landscape influences on water chemistry in Midwestern stream ecosystems. Freshwater Biol. 37(1), 193-208.

Johnson, L. and Gage, S. (1997) Landscape approaches to the analysis of aquatic ecosystems. Freshwater Biol. 37(1), 113-132.

Karr, J.R. (1999) Defining and measuring river health. Freshwater biology. 41(2), 221-234.

Ngoye, E. and Machiwa, J.F. (2004) The influence of land-use patterns in the Ruvu River watershed on water quality in the river system. Physics and Chemistry of the Earth 29(15), 1161-1166.

Osborne, L, and Wiley, M.J. (1988) Empirical relationships between land use/cover and stream water quality in an agricultural watershed. Journal of Environmental Management 26(1), 9-27.

Palmer, M.A. and Bernhardt, E.S. (2004). Ecological science and sustainability for a crowded planet. Report from the Ecological Society of America, www.esa.org/ecovisions.

Reimann, C., and Finne, T.E. (2009) The influence of geology and land-use on inorganic stream water quality in the Oslo region, Norway. Applied Geochemistry 24(10), 1862-1874.

Sang, G, and Gan, Z. (2003) Gully development and soil erosion in the Loess Yuan Region since Yuan Dynasty (in Chinese). Arid Land Geogr. 26(4), 355-360.

Sliva ,L, and Williams, D.D. (2001) Buffer zone versus whole catchment approaches to studying land-use impact on river water quality. Water Res. 35(14), 3426-3472.

Song, J.X. and Xu, Z.X. (2007) Ecological and environmental instream flow requirements for the Wei River-the largest tributary of the Yellow River. Hydrological Processes 21(8), 1066-1073.

Ye, Y. and He, X. (2014) Seasonal water quality upstream of Dahuofang Reservoir, China - the effects of land use type at various spatial scales. CLEAN-Soil, Air, Water 42, 1-10.

Zhao, J. (2008) Landscape pattern change and its environmental response across multiple spatial scales in tidal plain. East China Normal University, China. 